\title{
THE EFFECTIVENESS OF COOPERATIVE LEARNING MODEL OF NUMBERED HEAD TOGETHER (NHT) TYPE WITH GROUP INVESTIGATION (GI) TOWARD THE STUDENTS OF SMP MUHAMMADIYAH PLERET
}

\author{
Paradita Widyaswari ${ }^{\mathrm{a}}$, Harina Fitriyani ${ }^{\mathrm{b}}$ \\ Program Studi Pendidikan Matematika Universitas Ahmad Dahlan \\ Jalan Ring Road Selatan, Tamanan, Banguntapan, Bantul Yogyakarta \\ aparaditawidyaswari@gmail.com, ${ }^{\text {hharina.fitriyani@pmat.uad.ac.id }}$
}

\begin{abstract}
The use of a group learning model that has not varied and the students' role which less active in the learning process can influence the students learning outcome so that it is important to choose an innovative learning model where the students can involve in the learning process actively. The problem underlying the research by using a cooperative learning model which its types namely Number Head Together (NHT) and Group Investigation (GI). This research is conduct to know the effectiveness of cooperative learning model types NHT and GI toward the students of SMP Muhammadiyah Pleret grade VII in the academic year of 2015/2016. The population of this research was the student's grade VII of SMP Muhammadiyah Pleret in the academic year of 2015/2016. The sample collecting technique used in this research was random sampling and grade VII A was chosen as the class which is given cooperative learning with the NHT type and grade VII C as the class that using cooperative learning which is the type namely GI. The data collecting technique used test technique. The research instrument in this research was the mathematic result test which is the objective questions as the test questions. The instrument test includes validity, different power, and reliability. The data analyzing technique used the prerequisite test analysis which consists of a normality test and homogeneity test. The hypothesis test used a one-tailed ttest and a two-tailed t-test. Based on the calculation of the two-tailed t-test with significance level $\alpha=$ $5 \%$ and 55 degrees of freedom obtained $t_{c a l}=2,125403947$ and $t_{\text {table }}=2,0055$ and then $t_{c a l} \geq$ $t_{\text {table }}$ it means there are differences in the mathematic result study between students who use cooperative learning model types NHT with the students who use GI. One-tailed t-test with significance level $\alpha=5 \%$ and 55 degrees of freedom obtained $t_{\text {cal }}=2,125403947$ and $t_{\text {table }}=1,673925$ so $t_{\text {cal }} \geq t_{\text {table }}$ in conclusion, the student's mathematic learning outcome who uses cooperative learning model NHT is more effective than GI.
\end{abstract}

Keywords: Cooperative Learning Model, Numbered Head Together, Group Investigation.

\section{INTRODUCTION}

Education has a very important role in the progress of a nation, because through human education trying to develop every potential that exists in him. According to the Law of the Republic of Indonesia Number 20 of 2003 concerning the National Education System which explains that: Education is a conscious and planned effort to realize a learning atmosphere and learning process so that students actively develop their potential to have religious-spiritual strength, self-control, personality, intelligence, noble character, and skills needed by him, society, nation, and state.

Based on an interview with the mathematics teacher at SMP Muhammadiyah Pleret on October 13, 2015, information was obtained that the enthusiasm of students in attending the lesson was still lacking, some students were not paying attention to the lessons and were still lazy to work on the questions given by the teacher. Teaching and learning activities are not conducive because some students talk loudly about topics outside of mathematics when learning takes place. Also, student learning activeness is still lacking so the learning outcomes are not maximal. Learning activities carried out have used several learning methods by the material taught, among others: lecture methods, group discussions, and student activity sheets. For certain material, the teacher has applied to learn in groups, except that the group learning model has not varied, so the application of several learning methods has not been implemented optimally, so the learning outcomes are less satisfactory. This can be seen from the value of the even semester midterm Muhammadiyah Junior High School in the 2015/2016 academic year on mathematics subjects showing the learning outcomes of many class VII students who have not reached the minimum 
completeness criteria (MCC), which is 70. most students think mathematics is a difficult lesson to learn. This student's assumption causes students to be less active and motivated to learn mathematics. Besides, the group learning that has been implemented has not varied, so it is necessary to select innovative learning models where students can be actively involved in learning activities, one of which is the cooperative learning model.

Suprijono, Agus (2009: 54) argues that the cooperative learning model is a broader concept covering all types of group work including forms that are more led by the teacher or directed by the teacher." According to Shoimin, Aris (2014: 108) Numbered Head Together (NHT) is a model of group learning that each member of his group is responsible for the task of his group. This learning model aims to check students' understanding of the content of the lessons learned. According to Slavin in T, Taniredja, et al. (2011: 74) The development of Group Investigation cooperative learning is based on the premise that the learning process in schools concerns the area in the social and intellectual domains and the process that occurs is a combination of the values of the two domains." from this learning model is to train students to foster the ability to think independently and require students to have good abilities in communication and group process skills.

Therefore, the selection of NHT and GI type cooperative learning models is expected to create an interesting learning atmosphere, make students active and can improve student learning outcomes. The objectives to be achieved from the implementation of this research are:

1. To find out whether there are differences in mathematics learning outcomes using the cooperative learning model NHT Type and GI in class VII students in the even semester of SMP Muhammadiyah Pleret in the 2015/2016 academic year.

2. To find out what learning model is more effective between the NHT type cooperative learning model and the GI type cooperative learning model for the mathematics learning outcomes of class VII students in the even semester of SMP Muhammadiyah Pleret in the 2015/2016 school year.

\section{METHODS}

This research is a type of experimental research that is a research method used to find the effect of certain treatments on others under controlled conditions. The treatments carried out in this study that functioned as independent variables namely learning using the Numbered Head Together (NHT) type cooperative learning and Group Investigation (GI) models. The design used in this study was the posttestonly control design (Sugiyono, 2015: 112). In the design of this study using two classes, namely the first experimental class and the second experimental class. In the first experimental class, learning was done using Numbered Head Together (NHT) type cooperative learning while the second experimental class used Group Investigation (GI) cooperative learning.

The study was conducted at SMP Muhammadiyah Pleret in Bantul Regency 2015/2016 Academic Year on April 25 - May 21, 2016, even semester 2015/2016 academic year with 4 meetings (three treatments), and one study result test. The population in this study were all VII grade students of SMP Muhammadiyah Pleret consisting of classes, VII A, VII B, VII C, VII D. Sampling was carried out using random sampling technique that is taking sample classes by class drawing regardless of the strata because in the population of all homogeneous classes. After drawing a lot, class VII A was obtained as experimental class 1 (NHT), class VII C as experimental class 2 (GI) and class VII D as a trial class. The variables in this study were cooperative learning models as independent variables and mathematics learning outcomes of grade VII students of SMP Muhammadiyah Pleret in the 2015/2016 academic year as the dependent variable. The cooperative learning model used is Numbered Head Together (NHT) and Group Investigation (GI). Data collection techniques are documentation and tests, while the instruments used are questions related to the subject matter of the triangle in the form of tests of mathematics learning outcomes. In the instrument trial, the validity of the items was tested using the product-moment correlation formula, for the different power test questions using the distinguishing formula (Discriminant Index), while reliability testing used the formula Kuder Richardson-20 (KR-20). The data analysis technique consists of a prerequisite test for analysis and hypothesis testing. In the analysis prerequisite 
test, the homogeneity test and normality test were used. While testing the hypothesis using a one-party hypothesis test and testing the two-party hypothesis.

\section{RESULTS}

\section{Early Ability}

Table 1. Summary of Description of Initial Capability Value Data.

\begin{tabular}{|c|c|c|c|c|}
\hline Class & VII A & VII B & VII C & VII D \\
\hline Highest & 45 & 37,5 & 42,5 & 40 \\
\hline Lowest & 15 & 10 & 10 & 15 \\
\hline average & 27,734375 & 26,9642857 & 25,3 & 25,3448275 \\
\hline SD & 7,62951016 & 7,24431906 & 8,23862852 & 6,73888429 \\
\hline Variance & 58,2094254 & 52,4801587 & 67,875 & 45,4125615 \\
\hline $\mathrm{n}$ & 32 & 28 & 25 & 29 \\
\hline
\end{tabular}

Based on the homogeneity test calculation the initial ability value obtained $\chi_{c a l}^{2}=1.1248$ and according to the Chi-Square table at a significant level of $5 \%$ and $\mathrm{df}=\mathrm{k}-1=4-1=3$, obtained $\chi_{\text {table }}^{2}=\chi^{2}(0,05)(3)=7.8147$. Because $\chi_{\text {cal }}^{2}<\chi_{\text {table }}^{2}$ then $\mathrm{H}_{0}$ is accepted which means that the variance of the data of the initial values of the four classes is homogeneous.

After calculating the homogeneity test, a normality test is then carried out. In the NHT experimental class, obtained $\chi_{\text {cal }}^{2}=2,2222 \mathrm{~d}$ and according to the Chi-Square table at a significant level of 5\% and df $=\mathrm{k}-1=4-1=3$, obtained $\chi_{\text {table }}^{2}=\chi_{(0,05)(3)}^{2}=7.8147$. Because $\chi_{\text {cal }}^{2}<\chi_{\text {table }}^{2}$ then $\mathrm{H}_{0}$ is accepted so that it can be concluded that the data on the initial ability of students in the experimental class I (NHT) are normally distributed. The normality test in the GI experimental class was obtained $\chi_{\text {stat }}^{2}=0,8717$ and based on the Chi-Quadratic table at a significant level of $5 \%$ and $\mathrm{df}$ $=\mathrm{k}-1=3-1=2$ get $\chi_{\text {table }}^{2}=\chi_{(0,05)(2)}^{2}=5,9915$. Because $\chi_{\text {cal }}^{2} \leq \chi_{\text {table }}^{2}$, then $H 0$ is accepted, so it can be concluded that the data on the initial ability of students in the experimental class II (GI) are normally distributed.

Testing the hypothesis with a significant level of 5\% and degree of freedom 55, is obtained $t_{\text {table }}=2,005$, and $t_{\text {cal }}=1,5427$. Because $t_{\text {table }}<t_{\text {stat }}$ then $\mathrm{H} 0$ is accepted and $\mathrm{H} 1$ is rejected, so it can be concluded that there is no difference in the value of the initial ability between the NHT experimental class and GI experimental class VII grade students in the middle semester of the SMP Muhammadiyahin 2015/2016 academic year.

\section{Test Data on Mathematics Learning Outcomes}

Table 2. Summary of Description of Data on the Value of Mathematics Learning Outcomes

\begin{tabular}{|c|c|c|}
\hline Class & VII A & VII C \\
\hline Highest & 70 & 70 \\
\hline Lowest & 25 & 25 \\
\hline average & 46,71875 & 39,6 \\
\hline SD & 12,22170036 & 12,57643299 \\
\hline Variance & 149,3699597 & 158,1666667 \\
\hline $\mathrm{n}$ & 32 & 25 \\
\hline
\end{tabular}

Based on the calculation of the homogeneity test obtained $\chi_{\text {cal }}^{2}=0,0221$ and according to the ChiSquare table at a significant level of $5 \%$ and $\mathrm{df}=\mathrm{k}-1=2-1=1$, obtained $\chi_{\text {table }}^{2}=\chi^{2}(0,05)(1)=3,8415$. Because $\chi_{\text {cal }}^{2}<\chi_{\text {table }}^{2}$ then $\mathrm{H} 0$ is accepted which means that the variance in the value of the mathematics learning outcomes of the NHT experimental class students and the homogeneous GI experimental class. 
In calculating the normality test for the NHT experimental class, obtained $\chi_{\text {cal }}^{2}=1,6927$ and based on the Chi-Square table at a significant level of $5 \%$ and $\mathrm{df}=\mathrm{k}-1=5-1=4$ obtained $\chi_{\text {table }}^{2}=\chi^{2}(0.05)$ (4) $=9,4877$. Because $\chi_{\text {cal }}^{2} \leq \chi_{\text {table }}^{2}$, then $H_{0}$ is accepted, so it can be concluded that the data on the mathematics learning outcomes of the experimental class I (NHT) students are normally distributed. In the GI experimental class obtained $\chi_{\text {stat }}^{2}=4.4814$ and based on the Chi-Square table at a significant level of $5 \%$ and $\mathrm{df}=\mathrm{k}-1=4-1=3$, obtained $\chi_{\text {table }}^{2}=\chi_{(0.05)(3)}^{2}=7,8147$. Because $\chi_{\text {stat }}^{2} \leq$ $\chi_{\text {table }}^{2}$, then $H_{0}$ is accepted, so it can be concluded that the data values of students of experimental class II (GI) mathematics learning outcomes are normally distributed.

Hypothesis testing uses the two-party t-test the value of students' mathematics learning outcomes with a significant level of $5 \%$ and degrees of freedom $=55$, obtained by $t_{\text {cal }}=2.1254$. Because $t_{\text {cal }}>$ $t_{\text {table, }}$, then $\mathrm{H}_{0}$ is rejected and $\mathrm{H}_{1}$ is accepted, this means that there is a difference between the learning outcomes of mathematics using the NHT type cooperative learning model and those using the GI type cooperative learning model for seventh-grade students in the SMP Muhammadiyahin the 2015/2016 academic year.

For one-party test the value of learning outcomes with $\mathrm{df}=55$ and $\alpha=0.05$ was obtained table $=$ $t_{\alpha(55)}=1.673925$ and based on calculations obtained $t_{c a l}=2.1254$. Because $t_{\text {cal }}>t_{\text {table, }}$, then $H_{0}$ is rejected and $\mathrm{H}_{1}$ is accepted, this shows that the NHT cooperative learning model is more effective than GI type cooperative learning on mathematics learning outcomes in seventh-grade students in the SMP Muhammadiyahin of 2015/2016 school year.

\section{DISCUSSION}

The purpose of this study was to determine the effectiveness of the learning model between students who took learning using the NHT type cooperative learning model with students who took part in learning using the GI type of cooperative learning model on mathematics learning outcomes in the seventh grade of the semester of SMP Muhammadiyah Pleret of 2015 / 2016. This study involved two classes, namely class VII A with the number of students 32 students as experimental class I (NHT) and class VII C with the number of students 25 students as experimental class II (GI).

The results of the research on the test results of mathematics learning showed that the data were normally distributed and homogeneous. Then, according to the hypothesis that has been proposed, the hypothesis is tested using the two-party t-test and one-party t-test. Based on the results of the first hypothesis test, namely the two-party t-test of mathematics learning outcomes experimental class I (NHT) and the mathematics learning outcomes of Experiment II (GI) class obtained $t_{\text {cal }}=2.1254$ and $t_{\text {table }}=t_{\frac{1}{2}} \alpha^{(55)}$ $=2,0055$, because $t_{\text {cal }}>t_{\text {table }}$ then $\mathrm{H}_{0}$ is rejected and $\mathrm{H}_{1}$ is accepted, this means that there is a difference between the learning outcomes of mathematics using the NHT type cooperative learning model and those using the GI type cooperative learning model for class VII students in the even semester of SMP Muhammadiyah of 2015/2016 academic year.

Then to test the second hypothesis, namely the one-party t-test mathematics learning outcomes experimental class I (NHT) and the mathematics learning outcomes of Experiment II (GI) class obtained $\mathrm{t}_{\text {cal }}=2.1254$ and $\mathrm{t}_{\text {table }}=t_{\propto(55)}=1,673925$ because $\mathrm{t}_{\text {cal }}>\mathrm{t}_{\text {table }}$ then $\mathrm{H}_{0}$ is rejected and $\mathrm{H}_{1}$ is accepted, this shows that the NHT type of cooperative learning model is more effective than GI type cooperative learning on mathematics learning outcomes in VII grade students in the even semester of SMP Muhammadiyahin the 2015/2016 school year.

Based on the observations of researchers when using the cooperative learning model type NHT learning activities went well, students listened well when the teacher explained about the material at the beginning of learning, then when working on students worksheet seemed to work well together in solving problems. Most students are active and interact with friends in their group or ask questions to the teacher.

The NHT type of cooperative learning model can increase positive interactions between students in groups, and provide a positive influence on learning outcomes, this is indicated by an increase in mathematics learning outcomes of students who use NHT type cooperative learning models compared to 
students who take learning using the GI type cooperative learning model in the material for the seventh grade in the even semester of SMP Muhammadiyahin Pleret in the 2015/2016 academic year.

\section{CONCLUSION}

Based on the results of the research and discussion as described in CHAPTER IV, the research conclusions can be taken as follows:

1. There are differences in mathematics learning outcomes between students who use the NHT type cooperative learning model and mathematics learning outcomes of students who use the GI type cooperative learning model for class VII students in the even semester of SMP Muhammadiyahin the 2015/2016 school year. This is indicated by the results of the two-party hypothesis test with a significant level of $5 \%$ and 55 degrees of freedom, obtained $t_{\text {cal }}=2.125403947$ and $t_{\text {table }}=2.0055$ where $t_{\text {stat }}>t$ table, so $\mathrm{H}_{0}$ is rejected and $\mathrm{H}_{1}$ is accepted.

2. The NHT type of cooperative learning model is more effective than GI type cooperative learning on mathematics learning outcomes in VII grade students in the even semester of SMP Muhammadiyahin the 2015/2016 school year. This is indicated by the results of a one-party hypothesis test with a significant level of $5 \%$ and a degree of freedom 55, obtained by $t_{\text {cal }}=2.125403947$ and $t_{\text {table }}=$ 1.673925 where $t_{\text {cal }}>t_{\text {table, }}$, then $\mathrm{H}_{0}$ is rejected and $\mathrm{H}_{1}$ is accepted.

\section{SUGGESTION}

Students are expected to be more prepared and active in the learning process of mathematics in the classroom, students want to find information or subject matter to be studied and further enhance their sense of responsibility as students so they can get better learning outcomes. In the teaching and learning process, group learning models greatly help improve student learning activeness, therefore teachers should increase the variance of group learning models, including using NHT and GI cooperative learning models so that learning becomes more interesting and helps improve student activity and responsibility.

This research is expected to provide input to the school to always evaluate the teaching and learning process that occurs in the classroom so that the school can support the creation of new and more effective learning models and following the conditions of students to improve the quality of education in schools. this research can be a reference in compiling scientific work in the field of education and can be used as a reference for subsequent research specifically regarding the effectiveness of NHT and GI type cooperative learning models.

\section{REFERENCES}

Shoimin, Aris. 2014. 68 Model Pembelajaran Inovatif dalam Kurikulum 2013. Yogyakarta: Ar-Ruzz Media.

Sugiyono. 2015. Metode Penelitian Pendidikan Pendekatan Kuantitatif, Kualitatif, dan R\&D. Bandung: Alfabeta.

Suprijono, Agus. 2009. Cooperative Learning. Yogyakarta: Pustaka Belajar.

Taniredja, Tukiran, dkk. 2011. Model-Model Pembelajaran Inovatif. Bandung:Alfabeta. 